\title{
Effect of Nitrogen Fertilizer (Urea) Rate Application on Growth Performance of Potato (Solanum Tuberosum L.) on Vertisols of Central Highland of North Shewa, Ethiopia
}

\author{
Daniel Daka Godebo* Bizuayehu Desta Ashagrie Shenderu Tsegaye Belay \\ Debre Berhan University College of Agriculture and Natural Resource Sciences, Department of Plant Sciences, \\ Debre Berhan, Ethiopia
}

\begin{abstract}
A study was conducted to determine response of potato (Solanum Tuberosum L.) to different rates of nitrogen fertilizer (urea) applied as $0 \mathrm{~kg} / \mathrm{ha}, 81 \mathrm{~kg} / \mathrm{ha} 165 \mathrm{~kg} / \mathrm{ha}$ and $246 \mathrm{~kg} / \mathrm{ha}$ on vertisols of Debre Berhan university demonstration site which was located at central highlands(North Shewa) of Ethiopia. Treatments were arranged in RCBD design. Data was collected after $50 \%$ of plants were produced flower in which it was sampled randomly from center of plot. Application of Nitrogen Fertilizer urea $246 \mathrm{~kg} / \mathrm{ha}$ and $165 \mathrm{~kg} / \mathrm{ha}$ delayed days to flowering, increases stem length, above ground biomass, underground biomass, branch number, and stem number as compared to the control $(\mathrm{N}=0 \mathrm{~kg} / \mathrm{ha})$. It was observed that application of $165 \mathrm{~kg} \mathrm{urea} / \mathrm{ha}$ is required for optimum growth and performance of potato Gorebeilla variety on Vertisols of Debre Berhan in central high lands of Ethiopia.
\end{abstract}

Keywords: - Potato, gorebeilla variety, Nitrogen fertilizer, aboveground performance, underground performance, different Rate application

DOI: $10.7176 / \mathrm{ALST} / 80-01$

Publication date: April $30^{\text {th }} 2020$

\section{Introduction}

In Ethiopia variety trials conducted over several locations on different crop species clearly indicated that soil nutrient stress is most significant parameter controlling crop yield (Tamire 1989). Nevertheless, it is significant to note that fertilizer response is directly related to soil and crop types emphasizing that soils varying in fertility status and crop species respond differently to applied fertilizers. Low soil fertility is under lined as critical problem among several production limiting factors of the north shewa areas of Ethiopia. This area is one of oldest agricultural areas in Ethiopia and due to loss of soil fertility and shortage of land for grazing, it can now hardly support its population (Amare 1978); thus necessitating external supply of inorganic and organic fertilizer inputs to increase crop productivity.

Farmers in study area (North Shewa) are conscious of response of potato to applied nutrients and raise crop in homestead using farmyard manure and house hold garbage. They do not, know type and rate of fertilizers to be applied for individual crop species and cultivars for improving crop productivity, moreover, fertility status of soil and types of cultivars however, blanket national recommendation of $165 \mathrm{~kg} / \mathrm{ha}$ urea is being used for potato production in North Shewa, Ethiopia. One of major problems resulting in lower potato productivity in zone due to lack of fertilizer rate recommendations based on environmental conditions. To address this problem study was conducted with major objective of investigating effects of different rates of Nitrogen fertilizer (urea) on yield and yield components of potato grown on vertisols of central highland (North Shewa) of Ethiopia.

\section{Materials and Methods}

Description of Study Site

The experiment was conducted at Debre Berhan University College of Agriculture and Natural Resource Sciences Department of Plant Sciences Demonstration Site with Vertisols of North Shewa, Ethiopia. Experimental site is located at $39^{\circ} 38^{\prime} \mathrm{N}$ and $9^{0} 36^{\prime} \mathrm{S}$ at an elevation of 2780 masl. It is situated at about $130 \mathrm{~km}$ away from Addis, very close to main road of Dessie. Experiment was conducted mainly under irrigated condition. The areas mean annual temperature was $18.6^{\circ} \mathrm{C}$ (range 5.4-9.6) ${ }^{\circ} \mathrm{C}$ with mean annual rain fall of $1045.5 \mathrm{~mm}$.

\section{Experimental Treatment, Design and Procedures}

Potato variety Gorebeilla was used for study. Treatments used consisted of four levels of Nitrogen fertilizer (urea) $0 \mathrm{~kg} / \mathrm{ha}, 81 \mathrm{~kg} / \mathrm{ha}, 165 \mathrm{~kg} / \mathrm{ha}, 246 \mathrm{~kg} / \mathrm{ha}$. Half rate of Nitrogen fertilizer (urea) was applied at time of planting. Remaining half of Nitrogen fertilizer was applied 33 days after planting. Urea (46\%) fertilizer was used as source for Nitrogen fertilizer.

Experiment was arranged in a randomized complete block design (RCBD) replicated three times. Plot size was four rows of each $3 \mathrm{~m}$ long and well sprouted potato tubers were planted at a spacing of $75 \mathrm{~cm}$ between row 
and $30 \mathrm{~cm}$ between plants. Spacing between plot and replication was 0.5 and $1.0 \mathrm{~m}$ respectively.

\section{Data Collection}

Days to flowering was recorded when $50 \%$ of population attained flowering stage. Plant height was determined by measuring height from base of main shoot to apex at full blooming. Number of stems per hill was recorded as average stem count of 3 hills per plot reached at flowering stage, only stems arising from mother tuber were considered as main stems.

Above ground (Stem and leaves) and underground (roots and stolons) bio mass were recorded by taking average fresh biomass of 3 randomly selected plants per plot after fully flowering (after 85 days of planting).

\section{Data Analysis}

Data was analyzed using ANOVA table. Means were compared using least significant difference (LSD) test at $1 \%$ and $5 \%$ probability level.

\section{Result and Discussion}

Table 1- Growth Parameters of Potatoes as affected by Nitrogen fertilizer (urea) application

\begin{tabular}{ccccc} 
Treatment(Urea/kg) & $\begin{array}{c}\text { Day of } \\
\text { flowering }\end{array}$ & $\begin{array}{c}\text { Branch number } \\
\text { (per hill) }\end{array}$ & $\begin{array}{c}\text { Stem number } \\
\text { (Per hill) }\end{array}$ & Plant height \\
\hline 0 & $49^{\text {cd }}$ & $58^{\text {bd }}$ & $5^{\mathrm{d}}$ & $41^{\mathrm{d}}$ \\
81 & $50^{\mathrm{cb}}$ & $64 \mathrm{bc}$ & $5.33 \mathrm{c}$ & $44 \mathrm{c}$ \\
165 & $52^{\mathrm{ab}}$ & $70^{\mathrm{ab}}$ & $7^{\mathrm{b}}$ & $46^{\mathrm{b}}$ \\
246 & $54^{\mathrm{a}}$ & $75^{\mathrm{a}}$ & $8^{\mathrm{a}}$ & $49^{\mathrm{a}}$ \\
Level of significant & $*$ & $*$ & $* *$ & $* *$ \\
CV\% & $1.47 \%$ & $2.83 \%$ & $5.424 \%$ & $1.823 \%$ \\
\hline
\end{tabular}

** means it is highly significant at $1 \%$ and significant at $5 \%$

* Means it is highly significant at $5 \%$ and non-significant at $1 \%$

\section{Days of Flowering}

Table 1 above showed that treatment three (Urea $=165 \mathrm{~kg} / \mathrm{ha}$ ) flowered three days after treatment one (Urea $=0$ $\mathrm{kg} / \mathrm{ha}$ ) and two days after treatment two (Urea $=81 \mathrm{~kg} / \mathrm{ha}$ ) and treatment four (Urea $=246 \mathrm{~kg} / \mathrm{ha}$ ) also flowered four days after treatment two (Urea $=81 \mathrm{~kg} / \mathrm{ha}$ ) and five days after treatment one (Urea $=0 \mathrm{~kg} / \mathrm{ha}$ ). There was also a two day difference in flowering between treatment three (Urea $=165 \mathrm{~kg} / \mathrm{ha})$ and four (Urea $=246 \mathrm{~kg} / \mathrm{ha}$ ) even if it was insignificant.

Nitrogen fertilization delayed flowering. This is conformed with findings of Ojala et al. (1990) who observed that high Nitrogen fertilizer levels promoted excessive vegetative growth and delay flowering. Low soil Nitrogen fertilizer is known to be a factor limiting potato production in Ethiopia and many parts of world especially when there is adequate water supply (Harris 1992). Nitrogen fertilizer increased days of flowering and production of different plant part (Kirishnippa 1989).

The observation of current investigation support previous studies on effect of Nitrogen fertilizer on delays of prolong flowering (Kleinkept et al. 1987). In addition, Mulubirhan (2004) reported that Nitrogen fertilizer treatment significantly prolonged days to flowering. Present investigation showed that treatments without Nitrogen fertilizer flowered earlier than treatments having Nitrogen fertilizer and also treatments of high nitrogen fertilizer application showed more delay in flowering than those with less levels of Nitrogen fertilizer (urea).

\section{Branch Number}

Table1 above Showed that treatment three increased number of branches by 12 as compared to treatment one and by 6 as compared to treatment two. Whereas treatment four increased number of branches by 17 as compared to treatment one and by 11 as compared to treatment two. Even if there was insignificant $(p>0.05)$ difference between treatment one and two and also between treatment three and four. On other hand, treatment four was significantly $(\mathrm{p}<0.05)$ different from one and two.

Biomass yield increase in response to Nitrogen fertilizer indicates that Nitrogen could exert significant influence on biomass production and partitioning to different parts. Similarly, Moorby (1967) reported that 
Nitrogen fertilizer plays a significant role in production of stem and axillary branches. A significant $(p<0.05)$ increase in canopy in response to Nitrogen fertilizer is reported by Millard and Marshal (1986). Current investigation showed clearly, treatments without Nitrogen fertilizer (control) treatments encounter small number of branches while treatments with high level Nitrogen fertilizer possess large number of branches.

\section{Stem Number}

There was a significant $(\mathrm{p}<0.05)$ difference among treatments. Treatment four and three were highly significant as compared to treatment one and four. Although stem number is one of most important yield component in potato; present investigation shows that it was affected by increment of Nitrogen fertilizer which means number of tiller increased by Nitrogen fertilizer. In disagreement with the current study or investigation, different authors reported that stem number is determined by very early in ontogeny of plant (Lynch and Row 1997). Stem number is not influenced much by mineral nutrient rather by other factors such as storage condition of tubers, number of viable sprouts at planting, sprouts damage at time of planting and growing conditions(Allen 1978) physiological age of the seed tuber (Iritani 1968) variety (Lynch and

Tai 1989) and tuber size (Harris 1978). Therefore, increase in stem number might be due to the different tuber size that we have used as planting material.

\section{Plant Length}

As of most parameters, plant length was increased significantly $(\mathrm{p}<0.05)$ when amount of nitrogen fertilizer was increased. For instance, plant length of treatment four increased by $8 \mathrm{~cm}$ and $5 \mathrm{~cm}$ more as compared to treatment one and two respectively. Whereas plant length of treatment three increased by $5 \mathrm{~cm}$ and $2 \mathrm{~cm}$ as compared to treatment one and two respectively. Similarly, plant length of treatment two increased by $3 \mathrm{~cm}$ as compared to treatment one. Plant height increases in responses to fertilization treatment may be attributed to stem elongation. Nitrogen fertilizer increased potato plant height (Yibekal 1998).

So that, current investigation supports previous study when compared between treatment without nitrogen fertilizer $($ Urea $=0 \mathrm{~kg} / \mathrm{h})$ and treatment four $($ Urea $=246 \mathrm{~kg} / \mathrm{h})$ with nitrogen fertilizer there were a significant $(\mathrm{p}<$ 0.05) difference in potato stem height. Application of nitrogen fertilizer in current experiment showed significant $(\mathrm{p}<0.05)$ effect on potato plant height as a result, controlled group (Urea $=0 \mathrm{~kg} / \mathrm{h}$ ) was shortest in plant length. Whereas nitrogen fertilizer with urea of $246 \mathrm{~kg} / \mathrm{h}$ was tallest in height which was May caused by addition of Nitrogen (urea) fertilizer.

\section{Above Ground and Underground Weight}

Table 2. Above and underground biomass yield (g/hill) of potato as influenced by Nitrogen fertilizer (urea) application.

\begin{tabular}{lll}
\hline Treatment(Urea/kg) & Above ground weight $(\mathrm{g} /$ hill $)$ & Underground weight $(\mathrm{g} / \mathrm{hill})$ \\
\hline 0 & $366.04^{\mathrm{cd}}$ & $20.57^{\mathrm{d}}$ \\
81 & $399.62^{\mathrm{bc}}$ & $27.43^{\mathrm{c}}$ \\
165 & $406.66^{\mathrm{ab}}$ & $35.66^{\mathrm{b}}$ \\
246 & $432.04^{\mathrm{a}}$ & $30.76^{\mathrm{a}}$ \\
Level of significance & $*$ & $* *$ \\
CV \% & $2.95 \%$ & $6.02 \%$ \\
\hline
\end{tabular}

** means it is highly significant at $1 \%$ and significant at $5 \%$

* Means it is highly significant at 5\% and non-significant at $1 \%$

Increasing nitrogen fertilizer increased partitioning of assimilates to shoot rather than to tubers (Biemond and Vos 1992). Similarly effects of short photo periods, with holding nitrogen fertilizer increased to percentage of export assimilates from leaves and reduced activity of sucrose phosphates syntheses (Oparka et al. 1987). Nitrogen increased above ground biomass yield of potato. As observed from table 2 above shows that there is significant $(\mathrm{p}<0.05)$ variation between control $(\mathrm{Urea}=0 \mathrm{~kg} / \mathrm{h})$ and highly nitrogen fertilizer added treatment of four $(\mathrm{Urea}=246 \mathrm{~kg} / \mathrm{h})$. In terms of above ground weight for treatment One (Urea $=0 \mathrm{~kg} / \mathrm{h}$ ) showed lower weight, while treatment four $(\mathrm{Urea}=246 \mathrm{~kg} / \mathrm{h}$ ) showed greater weight, in general present investigation conformed previously done researches. Although Gunasona and Harris (1969) investigation showed that continuous supply of nitrogen fertilizer to plants promotes shoot and root growth while reducing tuberization in potato. Higher fertilizer response may be linked to increase in total area which in turn increased amount of solar radiation intercepted and more photos assimilates to tubers as Millard and Marshall (1986).

Nitrogen fertilizer significantly influenced underground weight comparison between two treatments of control $(\mathrm{Urea}=0 \mathrm{~kg} / \mathrm{h}$ ) and high rate of treatment four $(\mathrm{Urea}=246 \mathrm{~kg} / \mathrm{h}$ ) has significantly vary, in control (Urea $=0 \mathrm{~kg} / \mathrm{h}$ ) treatment observe that has lower weight compared to high rate of nitrogen fertilizer $($ Urea $=246 \mathrm{~kg} / \mathrm{h}$ ) which has higher weight, this implies that underground biomass of Gorebeilla variety potato is influenced by increment of Nitrogen fertilizer. 
From present investigation it was observed that, comparison between treatment one (Urea $=0 \mathrm{~kg} / \mathrm{h}$ ) and four $(\mathrm{Urea}=246 \mathrm{~kg} / \mathrm{h})$, both above ground weight and underground weight showed significant $(\mathrm{p}<0.05)$ variation in treatments. In general application of nitrogen fertilizer affected both underground and above ground weight of Gorebeilla potato variety.

\section{Conclusion}

Application of nitrogen fertilizer was affect days to flowering, stem length, above ground biomass weight, underground biomass, and branch number and stem number over control.

In most of growth parameters it was showed that treatment three (urea $=165 \mathrm{~kg} / \mathrm{h}$ ) and treatment four $($ urea $=246 \mathrm{~kg} / \mathrm{h})$ do not show a significant $(\mathrm{p}<0.05)$ difference even if both showed a similar response for a better yield. In terms of economy, treatment four needs a further expense as compared to treatment three. So that, this study strongly convinced use of treatment three should be taken as recommendation rate in order to be beneficial in terms of both yield and cost for studying area.

In addition to this, before application of nitrogen fertilizer for studying other essential nutrients of soil should be analyzed so that accuracy will be more increased.

\section{Acknowledgement}

I would like to express heartfelt thanks to my advisor Bizuayehu Desta(phD), for deep constructive ideas and devoting for his precious time to accomplish this research project. Besides Special thanks goes to offices, especially College of Agriculture and Natural Resource Science and Plant Science Department for cooperative supplying of nursery inputs and equipment's during time of research.

Finally, my thank go to my almighty God for his unlimited peace and patience in my life.

\section{References}

Alllen, E.,J. 1978. Plant density. In : P.M. Harris (Ed). The potato crop, the scientific basis for improvement. Chapman and Hall Ltd. London 278-326.

Amare, G. 1978. Cropping system in Africa; the Ethiopian case: proceeding of workshop on cropping system in African held at morocco, Tanzania 35-44.

Biemond, H. and Vos, j. 1992. Effects of nitrogen on the development and growth of potato plant. 2. Partitioning of dry matter, nitrogen and nitrate. Annals of Botany 70:37-45.

Gunasena, H.,P.,M. and Harris, P.,M. 1969. The effects of CCC and nitrogen on the growth and yield of the second early potato variety, Craig's Royal. Journal of Agricultural Science 73:245-259.

Harris, P., M. 1978. Mineral nutrition in potato crop: The scientific basis for improvement.(P.M. Harris, Ed.). chapman and Hall Lodon. Journal of plant sciences 195-243.

Harris, P., M. 1992. Mineral nutrition in potato crop: The scientific basis for improvement.(P.M. Harris, Ed.). chapman and Hall Lodon. Journal of plant sciences 162-209.

Iritani, W., M. 1968. Factors affecting physiological ageing (degeneration) of potato tuber used as seed. American Potato Journal 45:111-116.

Kleinkopf, G.,E., western, D.,T., wille, M.,J., and kleinscmidt, G., D.1987. Specific gravity of Russet Burbank potatoes. American Potatoes Journal 64:579-587.

Krishnippa, K.,S. 1989. Effect of fertilizer application on dry matter and NP and K accumulation in the potato at different stages of growth. Mysore Journal agricultural Science 23:249-354.

Lynch, D.,R. and Row, B., R.,G.1997. Population density studies with russet Burbank potatoes, II. The effect of fertilization and plant density on growth, development, and yield. American Potato Journal 54-71.

Lynch, D., R. and Tai, G., C., C. 1989. Yield and yield component response of eight potato genotypes to water stress. Alliance of crop, soil, and Environmental Science Societies 29:1207-1211.

Millard, P. and Marshall, B. 1986. Growth, nitrogen uptake and partitioning with in the potato crop (Solanum Tuberasum L.) in relation to nitrogen application. Journal of Agricultural Science 107:421-429.

Moorby, J. 1967. Inter- stem and inter- tuber competition in potatoes. European potato journal 10: 180-205.

Mulubrhan, H. 2004. The effect of nitrogen, phosphorus and potassium fertilization on the yield and yield components of potato solanum tuberosum L., grown on vertisols of mekele area. M.sc thesis, Alemaya University, Ethiopia 1-24

Ojala, J., C., Stark, J. and Kleinkopf, G.C. 1990. Influence of irrigation and nitrogen management on potato yield and quality. American Potato Journal 67:29-44.

Oparka, K., J., Davies, H.,V. and Prior, D.,A.,M. 1987. The influence of applied Nitrogen on export and partitioning of current assimilate by field grown potato plants. Annals of Botany. 59:311-323.

Painter, C., G. and Augustine, J. 1976. The effect of soil moisture and nitrogen on yield and quality of the Russet Burbank potato. American Potato Journal 53:275-284.

Tamirie, H. 1989. Increasing Agricultural production through improved soil, water, and crop management 
practices in proceedings of national workshop on food strategies for Ethiopian held at Alemaya University of Agriculture 8-12 December 1986, Ethiopia 243-275.

Yibekal, A. 1998. Effects of Nitrogen and phosphorus on yield and yield components, and some quality traits of potato (Solanum Tuberosum L.) at Wondo Genet areas. M.Sc. Thesis, Alemaya University of agriculture, Ethiopia 1-82. 